\title{
Improvement of Biowaste Composting Efficiency using Sphingobacterium spiritivorum
}

\author{
Marija Vuković Domanovac', Vedran Vučić1, Dajana Kučić Grgić1, Monika Šabić Runjavec1, \\ Marijana Vidaković ${ }^{1}$, Martina Sudar ${ }^{1}$, Bruno Zelić ${ }^{1}$ \\ ${ }^{1}$ University of Zagreb, Faculty of Chemical Engineering and Technology \\ Marulićev trg 19, HR-10000 Zagreb, Croatia \\ mvukovic@fkit.hr
}

\section{Extended Abstract}

Due to generation of large quantities of waste [1], waste management has grown to become one of the biggest challenges these days. From economic and social to environmental factors, waste management and waste disposal need better management system because problems are often connected with technically weak waste management system, insufficient financial resources and often limited cooperation from public [2]. In order to cope better with this situation, waste is divided into fractions. Organic fraction of municipal solid waste is one of the classifications made to better adjust approach for recycling of biodegradable waste material. In the attempt to switch from linear to circular economy, the most common way of disposal organic fraction of municipal solid waste in the landfills has become the least favourable solution [3]. As a right step towards recycling biodegradable organic fraction of municipal solid waste, as a part of circular economy, environmentally and economical acceptable, composting found its place in the waste management. Because of benefits such as sanitization of waste, cost effectiveness and conversion of waste to valuable product, composting is considered as reliable biodegradable waste treatment option [1].

Composting is a natural aerobic degradation process conducted and catalyzed by microorganisms, carried out under controlled conditions. To improve composting process regarding enhanced biodegradation, acceleration, nutrient content and ratios, reduction of gas emissions, reduction of leachate generation, various additives could be used. Addition of biological agents, such as specific microbe population specifically applied through bioaugmentation, can affect composting process greatly toward faster and better conversion of biodegradable material in to useful products [4]. Many biodegradation studies have focused on survival of isolated bacteria to increase the bacteria population and subsequently enhance the efficiency of biodegradation [5].

The primary aim of this study is to enhance and accelerate biodegradation of biowaste by composting process in closed reactor system. Biological waste from households, originating from gardens and yards, was designated as a substrate for reactor composting. To investigate the effect of microorganisms in the composting process, one bacterial isolate from biowaste compost was selected. Experiments were performed in two reactors with (R1) and without (R2) bioaugmentation during 6 days. Bacteria culture Sphingobacterium spritivorum has been isolated, identified and bioaugmented in reactor R2. Initial values for the experiments were respectively, volatile matter $58.27 \%$, moisture content $71 \%, \mathrm{C} / \mathrm{N}$ ratio 14.47 , and $\mathrm{pH}$ 7.46. In the reactors, on day 6 of composting process, conversions were $23.90 \%$ and $38.22 \%$ for R1 and R2 respectively. At the end of the experiments, emissions of $\mathrm{CO}_{2}$ and $\mathrm{NH}_{3}$ were $236.65 \mathrm{~g} / \mathrm{kg}_{\mathrm{VM} 0}$ and $317.83 \mathrm{mg} / \mathrm{kg}$ vм0 for R1, and 259.40 $\mathrm{g} / \mathrm{kg}_{\mathrm{VM} 0}$ and $97.33 \mathrm{mg} / \mathrm{kg}_{\mathrm{VM} 0}$ for $\mathrm{R} 2$. C/N ratios were 12.25 and 11.55 for R1 and R2 respectively. In conclusion, $S$. spiritivorum showed promising capacity for improving and accelerating the reactor composting process and positive influence on $\mathrm{NH}_{3}$ emission reduction.

\section{References}

[1] C. O. Onwosi, V. C. Igbokwe, J. N. Odimba, et al., "Composting technology in waste stabilization: On the methods, challenges and future prospects," J. Environ. Manage., vol. 190, pp. 140-157, 2017.

[2] L. Makarichi, K. A. Techato and W. Jutidamrongphan, "Material flow analysis as a support tool for multi-criteria analysis in solid waste management decision-making," Resour. Conserv. Recycl., vol. 139, pp. 351-365, 2018. 
[3] M. D. Vaverkova, J. Elbl, M. Radziemska, et al., "Environmental risk assessment and consequences of municipal solid waste disposal," Chemosphere, vol. 208, pp. 569-578, 2018.

[4] J. Barthod, C. Rumpel and M. F. Dignac, "Composting with additives to improve organic amendments. A review," Agron. Sustainable Dev., vol. 38, p. 23, 2018.

[5] N. A. Mohd-Kamil, N. H. Hussain, M. B. Mizad, et al., "Enhancing performance of Sphingobacterium spiritivorum in bioremediation phenanthrene contaminated sand," Remediation J., vol. 24, pp. 119-128, 2014. 